\title{
Quantification of micropollutants in some water sources in northern Tanzania
}

\section{${ }^{1}$ HARIETH HELLAR-KIHAMPA}

Institute of Continuing Education, The Open University of Tanzania, P. O. Box 23409, Dar es Salaam, Tanzania

*Correspondence: Tel. +255 784443 157; Email: hhellar@yahoo.co.uk; hariet.hellar@out.ac.tz

\begin{abstract}
The loading of micropollutants in freshwater ecosystems to levels exceeding their waste assimilative capacity is a threat to both ecology of the ecosystems and health of the resource users. Some chemical species are of much concern due to their persistence, bioaccumulative and toxicity nature, even at trace levels, while others are of concern due to their contribution to eutrophication, oxygen depletion and other disruptive changes. Despite contamination threats from human activities around catchment areas in Tanzania, specific extent of the impacts are rather not well investigated. In this work, we quantified concentration levels of some major elements, trace elements, dissolved inorganic ions, nutrients and organochlorine pesticide residues in river water and sediments from northern Tanzania. Information on land use practices in the area, which represents potential sources of contamination, was gathered. Samples were collected from pre-selected stations in two different seasons and characterized for physico-chemical parameters. Preparation and instrumental analysis of samples was done by standard analytical protocols. Obtained results indicated contamination by some micropollutants, including some dissolved ionic species in water: $\mathrm{Na}^{+}(>200 \mathrm{mg} / \mathrm{l}), \mathrm{K}^{+}(>25$ $\mathrm{mg} / \mathrm{l}), \mathrm{Mg}^{2+}(>50 \mathrm{mg} / \mathrm{l})$ and $\mathrm{NO}_{3}^{-}-\mathrm{N}(>80 \mathrm{mg} / \mathrm{l})$. High concentrations of some toxic metals were also measured in sediment samples, including V $(325 \mathrm{mg} / \mathrm{kg}), \mathrm{Cr}(270 \mathrm{mg} / \mathrm{kg}), \mathrm{Cu}(114$ $\mathrm{mg} / \mathrm{kg}), \mathrm{Ni}(85 \mathrm{mg} / \mathrm{l})$ and $\mathrm{Zn}(355 \mathrm{mg} / \mathrm{kg})$. Low levels of organochlorine pesticide residues were measured. Concentration levels were compared to water and sediment quality guidelines to establish their ecotoxicological risk implications. (C) JASEM
\end{abstract}

http://dx.doi.org/10.4314/jasem.v20i3.8

Keywords: Micropollutants; Surface water; Sediments; Contamination; Tanzania

\section{Introduction}

Contamination of water sources is one of the major problems facing the water sector today in both developed and developing countries. This is mainly due to rapid population growths, expansions of social-economic activities, technological advancements and climatic changes. It is reported that more than half of the world's freshwater resources are seriously depleted and contaminated by inputs from various sources (WCW, 1999), including industrial effluents, municipal sewage plants, runoffs from urban and agricultural areas, mining and smelting activities, leachates from improperly disposed solid wastes on open surfaces and landfills as well as atmospheric depositions (Eggen et al., 2010; Fitzpatrick et al., 2007). Micropollutants are unwanted organic or inorganic substances that are added to water in extremely low concentrations, in the order of microgram per litre or even nanogram per litre. Some of these substances have toxic, persistent and bioaccumulative properties that may have negative physical, chemical and biological effects on the environment, organisms and human health. Effects of water contamination are many and may range from simple nuisance to inadequate water supply to severe ecotoxicological impacts (Manahan, 2005).
In Tanzania, despite the existence of pollution potential from a number of sources, the amount and scope of scientific investigations addressing the problem of micropollutants are rather limited (Kishimba et al., 2003; Ngoye and Machiwa, 2004). Relatively little data is available on the distribution of micropollutants in the freshwater resources in the country. The northern part of the country, which includes the administrative regions of Arusha, Manyara, Kilimanjaro and Tanga, is one of the most agricultural intensive areas in the country, especially due to favorable climatic conditions and the rich volcanic soils from the slopes of Mount Kilimanjaro (Hellar-Kihampa, 2011). The upper part of the area is characterized by urbanization and densely populated rural settlements. The lowlands have scattered croplands associated with smaller settlements, usually close to rivers (Beuster et al., 2006). Agriculture is the main land use sector in the area, for example, the sugarcane plantations at Arusha Chini in Kilimanjaro region have been operational since early 1940s with an over sixty years history of pesticide use.

Analysis of surface waters collected close to the plantations in the past revealed contamination by different types of pesticide residues (Hellar-Kihampa, 2011; Hellar and Kishimba, 2005). The regions are also among the few areas that produce flowers for export in Tanzania. The rapid growing flower 
industry is chemically intensive, thus associated with environmental contamination (Msogoya, and Maerere, 2006), especially of surface waters. Smallscale farmers make use of the streams and rivers to grow a variety of crops such as fruits and vegetables. However, most of these crops are grown close to water sources, increasing the risk of surface water contamination from agrochemicals. Livestock keeping also poses contamination threat, especially in the highland and upper areas where households keep large numbers of cattle, goats and sometimes sheep. There is also a large concentration of pastoral communities, who are nomadic and depend on livestock for their livelihoods. A range of other social-economic activities, including agro-industries, mining and natural resources harvesting are also potential sources of contamination to surface water.

Although some studies were conducted in the past to investigate quality of water sources in the area, there is still relatively little data on the actual levels, distributions and ecological implications of different types of micropollutants. Therefore in an effort to narrow down that information gap, this study quantified a range of micropollutants, including dissolved ions, nutrients, trace elements, pesticide residues and organic contaminants in water and sediment. The main objective was to establish the contamination levels, identify possible sources of the contaminants and assess their possible ecotoxicological effects.

\section{MATERIALS AND METHODS}

Sample collection: Water and sediment samples were simultaneously collected from 12 pre-selected sampling stations described in Table 1. The stations are among those periodically monitored by the Pangani River Basin Water Board (PBWB).

Table 1: Sampling locations

\begin{tabular}{|c|c|c|c|c|}
\hline Site Code & River/Location & Coordinates & $\begin{array}{l}\text { Elevation } \\
\text { (AMSL) }\end{array}$ & Site Description \\
\hline S1 & $\begin{array}{l}\text { Kikuletwa River at } \\
\text { Karangai }\end{array}$ & $\begin{array}{l}\mathrm{S} 03^{\circ} 26.44 \\
\mathrm{E} 036^{\circ} 51.27\end{array}$ & $1020 \mathrm{~m}$ & $\begin{array}{l}30 \mathrm{~km} \text { from Arusha Municipality. Extensive livestock } \\
\text { farming and horticultural activities. }\end{array}$ \\
\hline S2 & $\begin{array}{l}\text { Kikavu River at Kikavu } \\
\text { Chini }\end{array}$ & $\begin{array}{l}\mathrm{S} 03^{\circ} 26.22 \\
\mathrm{E} 037^{\circ} 18.05\end{array}$ & $1019 \mathrm{~m}$ & $10 \mathrm{~km}$ from Moshi town close to sugarcane plantations. \\
\hline S3 & $\begin{array}{l}\text { Kikuletwa River at Msitu } \\
\text { wa Tembo }\end{array}$ & $\begin{array}{l}\mathrm{S} 03^{\circ} 33.00 \\
\mathrm{E} 037^{\circ} 18.25\end{array}$ & $741 \mathrm{~m}$ & $25 \mathrm{~km}$ from Moshi town close to sugarcane plantations. \\
\hline S4 & Ruvu River at Kifaru & $\begin{array}{l}\mathrm{S} 03^{\circ} 31.35 \\
\mathrm{E} 037^{\circ} 33.42\end{array}$ & $709 \mathrm{~m}$ & $\begin{array}{l}\text { Upstream Nyumba ya Mungu dam. Along the Dar es } \\
\text { Salaam highway. }\end{array}$ \\
\hline S5 & Ruvu River at Tingatinga & $\begin{array}{l}\text { S } 03^{\circ} 33.17 \\
\text { E } 037^{\circ} 29.09\end{array}$ & $702 \mathrm{~m}$ & $\begin{array}{l}\text { Upstream Nyumba ya Mungu hydropower station, } 8 \mathrm{~km} \\
\text { from the Dar es Salaam highway. }\end{array}$ \\
\hline S6 & $\begin{array}{l}\text { Pangani River at Nyumba } \\
\text { ya Mungu }\end{array}$ & $\begin{array}{l}\text { S } 03^{\circ} 50.18 \\
\text { E } 037^{\circ} 27.31\end{array}$ & $669 \mathrm{~m}$ & $\begin{array}{l}\text { Downstream Nyumba ya Mungu hydropower station, } \\
20 \mathrm{~km} \text { from the Dar es Salaam highway. }\end{array}$ \\
\hline S7 & Pangani River at Buiko & $\begin{array}{l}\text { S } 04^{\circ} 38.58 \\
\text { E } 038^{\circ} 02.34\end{array}$ & $534 \mathrm{~m}$ & Along the Dares Salaam highway. \\
\hline S8 & Mkomazi River at Makayo & $\begin{array}{l}\text { S } 04^{\circ} 39.35 \\
\text { E } 038^{\circ} 04.36\end{array}$ & $450 \mathrm{~m}$ & $\begin{array}{l}\text { Along the Dares Salaam highway. Irrigated rice } \\
\text { farming upstream the station. }\end{array}$ \\
\hline S9 & Pangani River at Korogwe & $\begin{array}{l}\mathrm{S} 05^{\circ} 09.50 \\
\mathrm{E} 038^{\circ} 28.22\end{array}$ & $287 \mathrm{~m}$ & $2 \mathrm{~km}$ from Korogwe town, $1 \mathrm{~km}$ from highway \\
\hline S10 & Pangani River at Hale & $\begin{array}{l}\mathrm{S} 05^{\circ} 17.37 \\
\mathrm{E} 038^{\circ} 36.06\end{array}$ & $266 \mathrm{~m}$ & $\begin{array}{l}\text { Downstream Hale hydropower station, along the } \\
\text { highway. Close to a slaughterhouse. }\end{array}$ \\
\hline S11 & Pangani River at Mseko & $\begin{array}{l}\mathrm{S} 05^{\circ} 24.26 \\
\mathrm{E} 038^{\circ} 52.04\end{array}$ & $06 \mathrm{~m}$ & $\begin{array}{l}\text { Inlet to the Indian ocean. } 50 \mathrm{~km} \text { from Tanga } \\
\text { municipality, } 20 \mathrm{~km} \text { from Pangani town. }\end{array}$ \\
\hline $\mathrm{S} 12$ & $\begin{array}{l}\text { Soni River at Soni, } \\
\text { Lushoto }\end{array}$ & $\begin{array}{l}\mathrm{S} 04^{\circ} 50.27 \\
\mathrm{E} 038^{\circ} 22.09\end{array}$ & $1182 \mathrm{~m}$ & $\begin{array}{l}20 \mathrm{~km} \text { from Mombo town, a few metres from vegetable } \\
\text { farms. }\end{array}$ \\
\hline
\end{tabular}

Sampling campaigns were conducted during the dry season (September - October) and rainy season (March - April). With the aid of a Global Positioning System (GPS) receiver, samples were collected from exactly the same locations during the two seasons.

Water samples for inorganic contaminants were collected by grabbing in pre-cleaned polyethylene bottles and preserved by acidification with a few drops of concentrated $\mathrm{H}_{2} \mathrm{SO}_{4}$. Water samples for analysis of organic contaminants were collected in 1 L glass sampling bottles with Teflon caps that were previously cleaned with de-ionized water and thoroughly rinsed with acetone. The samples were unfiltered and preserved with $\sim 100 \mathrm{~g}$ of $10 \% \mathrm{NaCl}$.
Sediment samples were collected by scooping (0-6 $\mathrm{cm}$ depth) using a stainless steel scoop, wrapped in aluminium foils and stored in polyethylene bags. Both water and sediment samples were stored in cold boxes and transported to the Department of Chemistry, University of Dar es Salaam for further processing.

Sample characterization: Water samples were characterized on-site for some key physico-chemical water quality parameters using calibrated hand-held portable monitors (Hach Co., USA). Parameters that were measured on site were temperature, $\mathrm{pH}$, Electric 
Conductivity (EC), Total Dissolved Solids (TDC) and Dissolved Oxygen (DO).

Sediment samples were characterized for their physico-chemical parameters, including $\mathrm{pH}$, water content, organic matter content, carbonate content and percentage of silt-clay at the Department of Chemistry and the Department of Geology, University of Dar es Salaam, using standardized methods.

Sample analysis: Instrumental analyses for the targeted groups of micropollutants were carried out in laboratories at the University of Dar es Salam (USDM), Ardhi University (ARU) and the Government Chemistry Laboratory Agency (GCLA) in Tanzania and at the Departments of Chemistry and Biology, University of Antwerp in Belgium.

Water samples for determination of dissolved ions were filtered by a Millex®-GC $0.22 \mathrm{~mm}$ polyvinylidene difluoride (PVDF) membrane filter unit (Millipore, Ireland), while sediment samples were leached in high purity Milli-Q water in an ultrasonic bath (Bransonic, 2210, USA) at the Department of Chemistry, University of Antwerp. Samples were then analyzed by a Dionex DX-120 Ion chromatography (Dionex, USA) for concentrations of seven anions $\left(\mathrm{SO}_{4}{ }^{2-}, \mathrm{NO}_{3}{ }^{-}, \mathrm{F}^{-}, \mathrm{Br}^{-}, \mathrm{Cl}^{-}, \mathrm{NO}_{2}{ }^{-}, \mathrm{PO}_{4}{ }^{3-}\right)$ and six cations $\left(\mathrm{NH}_{4}^{+} \mathrm{Li}^{+}, \mathrm{K}^{+}, \mathrm{Na}^{+}, \mathrm{Mg}^{2+}, \mathrm{Ca}^{2+}\right)$.

Colorimetric determination of inorganic nutrients $\left(\mathrm{NO}_{3}{ }^{-}-\mathrm{N}, \quad \mathrm{NO}_{2}^{-}-\mathrm{N}, \mathrm{NH}_{3}-\mathrm{N}\right.$ and $\left.\mathrm{PO}_{4}{ }^{3-}-\mathrm{P}\right)$ in water and sediments was done at the analytical chemistry laboratory, Department of Chemistry, University of Dar es Salaam, Tanzania using the APHA method (APHA/AWWA/WEF, 2005).

Sediment samples for determination of major elements ( $\mathrm{Si}, \mathrm{Al}, \mathrm{Fe}, \mathrm{Ca}, \mathrm{K}, \mathrm{Ti}, \mathrm{Mn}$ and $\mathrm{P}$ ) were freeze-dried, sieved and made into press-powder pellets. They were then analyzed by an Epsilon 5 High-energy Polarized Beam EDXRF spectrometer (PANalytical, Almelo, The Netherlands) at the Department of Chemistry, University of Antwerp, Belgium.

Preparation of water samples and instrumental analysis by Atomic Absorption Spectrometry (AAS) for determination of trace elements was carried out at the Laboratory of the School of Environmental Science and Technology, ARU, Dar es Salaam. Sediment samples for trace elements analysis were prepared and analysed at the Department of Biology, University of Antwerp. Previously freeze-dried sediment samples for were homogenized and extracted by microwave assisted acid-digestion using aqua-regia $\left(1: 3 \quad \mathrm{HNO}_{3}: \mathrm{HCl}\right)$, also called nitrohydrochloric acid, in an ETHOS 900 micro-wave system (Milestone, Shelton, CT, USA) as detailed in
Hellar-Kihampa et al., (2014). Samples were then analysed by Inductively Coupled Plasma - Mass Spectrometry (ICP-MS) for concentrations of $\mathrm{Pb}, \mathrm{Cu}$, $\mathrm{Cr}, \mathrm{Ni}, \mathrm{Cd}, \mathrm{Co}, \mathrm{As}, \mathrm{V}, \mathrm{Mn}$ and $\mathrm{Zn}$.

For determination of organochlorine pesticide residues, water samples were extracted by the liquidliquid extraction method using dichloromethane at the Department of Chemistry, UDSM and analyzed by a CP-3800 VARIAN Gas Chromatography (GC) at the GCLA, while sediment samples were extracted by the Soxhlet extraction method using chromatographic grade hexane/acetone mixture, (3:1, v/v) (Merck KGaA, Darmstadt, Germany) and analysed by an Agilent 6890GC-5973MS Gas Chromatography Mass Spectrometry (GC-MS) operated in electron ionisation (EI) mode and equipped with a $25 \mathrm{~m} \mathrm{x} 0.22$ $\mathrm{mm} \times 0.25 \mu \mathrm{m}$ HT-8 capillary column (SGE, Zulte, Belgium) at the University of Antwerp. The quality of the analytical data was assured by the analysis of blanks, duplicate samples, internal standards as well as Certified Reference Materials according to the standard operating procedures of the analytical laboratories involved.

Data analysis: For interpretation of the data set, the following statistical analyses were used; descriptive statistics (range, mean and standard deviations) were computed from the instrumental measurements. Correlation analyses were used to evaluate interrelationships between various parameters, with statistical significance set at $\mathrm{p}<0.05$. Nonparametric test for two independent variables $(95 \%$ confidence interval) was employed to compare the concentrations of individual elements between the two seasons. Considered significant differences were those with $\mathrm{p}$ $<0.05$. Statistical analyses were performed by using the statistical package SPSS Statistics 17.0.

\section{RESULTS AND DISCUSSIONS}

Physio-chemical water quality parameters: Results of the water quality parameter measured in this study showed that $\mathrm{pH}$ valued of the river waters were near neutral to slightly alkaline $(6.77 \pm 0.34-8.94 \pm 0.45)$. These values are of usual range for natural river water (Chapman and Kimstach, 1996) and are also within the WHO maximum permissible limits of 6.5-9.2 for potable water (WHO, 2004). The highest $\mathrm{pH}$ values for both seasons were recorded at station S6 and the lowest at station S2. Comparison by the Wilcoxon Signed Ranks non-parametric test confirmed that the $\mathrm{pH}$ values of the water samples were generally higher during the dry season than in the rainy season.

Water temperatures were all above $20{ }^{\circ} \mathrm{C}$ ranging from $21.0{ }^{\circ} \mathrm{C}$ to $30.5{ }^{\circ} \mathrm{C}$, reflecting the climatic conditions of the area, and were observed to be higher during the rainy season for all the 12 stations. The lowest temperatures were recorded at station S12, which is the coolest part of the basin, being located in 
Lushoto area, which is at the highest elevation of all the sampled locations, while the highest temperatures were recorded at station S11, Pangani area, which is a coastal area at almost sea level where air temperatures are higher.

Electric Conductivity varied greatly among the sampling sites, ranging between 97 and $1350 \mathrm{mS} / \mathrm{cm}$. Normally the EC of natural waters is expected to vary between 50 and $1500 \mu \mathrm{S} / \mathrm{cm}$ (Bartram and Ballance 1996), whereas the WHO maximum permissible value for potable water is $2500 \mu \mathrm{S} / \mathrm{cm}$ (WHO, 2004). The highest value of EC was recorded at station S2 during the dry season. The sharp increase in EC during the dry season in this site reflects anthropogenic inputs of dissolved solutes. Station S2 is close to the urbanized Moshi town, sugarcane plantations and the sugar industry, therefore high EC at the station might be due to increased dissolved salts from the irrigation channels, discharges from the sugarcane fields and contaminated run-offs from the urban centre.

The TDS ranged between 48 and $652 \mathrm{mg} / \mathrm{L}$, which was within the WHO acceptable standard for drinking water quality of $1000 \mathrm{mg} / \mathrm{L}$ (WHO, 2004). The highest TDS concentration was measured at station S2 during the dry season, which anomalously increased from $48 \mathrm{mg} / \mathrm{L}$ that was measured at the station during the rainy season. The changes in the TDS values observed in the sampling stations during the two seasons reflect changes in the river dynamics such as quantities of the dissolved solids. As expected, the spatial distribution of TDS follows exactly the same trend as that of EC, and the two parameters are highly correlated.

Dissolved-oxygen (DO) concentrations were found to range between 2.0 and $8.3 \mathrm{mg} / \mathrm{L}$ (at $25^{\circ} \mathrm{C}$ ), with oxygen saturation ranging between $22.7 \%$ and $112 \%$. The DO concentrations were general lower during the dry season. The concentrations of DO in unpolluted water are normally about $8.0-10 \mathrm{mg} / \mathrm{L}$ at $258 \mathrm{C}$ (DeZuane, 1997). The three most upstream stations (S1, S2 and S3) recorded the highest concentrations of DO, while station S4 (the Ruvu river at Kifaru) had the lowest concentrations $(2.0 \mathrm{mg} / \mathrm{L})$ that were even below the minimum recommended level of 2.4 $\mathrm{mg} / \mathrm{L}, 30 \%$ at $25^{\circ} \mathrm{C}$ for the protection of aquatic life (DeZuane, 1997).

The low oxygen concentrations at station S4 were associated with the amounts of organic matter, including decaying aquatic weeds (Cyperus papyrus), which could be physically observed. Decomposition of organic matter is one cause of oxygen depletion in freshwater systems (Schlautman and Han, 2001).
Generally, the physicochemical water quality parameters reported in this study differ slightly from those previously reported by PBWB/IUCN (2007) in terms of increased water temperature and lowered values of EC and DO in the present study. This might be due to many changes that might have occurred, such as weather conditions, human activities and natural inputs since river systems are always dynamic.

Physico-chemical sediment parameters: The sediment samples displayed a wide variability of organic matter $(5.2 \pm 0.4$ to $22.5 \pm 1.8 \%)$ and water content $(22.3 \pm 1.17$ to $54.0 \pm 2.7 \%)$. The highest organic matter content was found at station S12, and the highest water content was at station S9. High organic matter increases the expectation that the sediment will tend to accumulate metals, whereas clay content determines the metal retention and availability in sediments.

The carbonate analysis indicated that the sediment samples had carbonate contents of $\approx 5.0-25.7 \%$ dry weight (mean values). Sediment $\mathrm{pH}$ values measured were neutral to slightly alkaline $(\mathrm{pH} 6.72 \pm 0.34$ to $8.07 \pm 0.41)$ reflecting those of the water, with the highest value at S6 and the lowest at S12. The distribution of sediment particle sizes into clay $(<2$ $\mu \mathrm{m})$, silt $(2-63 \mu \mathrm{m})$ and sand $(63 \mu \mathrm{m}-2 \mathrm{~mm})$ fractions revealed that sand was dominant in samples from all stations $(41-91 \%)$, followed by silt $(8-$ $49 \%)$ and clay $(1-13 \%)$.

Dissolved ionic species: Concentration ranges of the water soluble ionic species measured in water and sediment samples in this study are summarised in Table 2 .

The ions, $\mathrm{Li}^{+}, \mathrm{NH}_{4}{ }^{+}$and $\mathrm{PO}_{4}{ }^{3-}$ were below the method quantification limits in both water and sediments. The abundance of the major cations were generally in the order $\mathrm{Na}^{+}>\mathrm{Ca}^{2+}>\mathrm{Mg}^{2+}>\mathrm{K}^{+}$; while that of the anions were in the order $\mathrm{HCO}_{3}{ }^{-}>\mathrm{SO}_{4}{ }^{2-}>\mathrm{Cl}^{-}>\mathrm{F}^{-}>$ $\mathrm{Br}^{-}$in both water and sediments. The average total ionic load ( $\sum$ cations $+\sum$ anions) ranged from $205-$ $1195 \mathrm{mg} \mathrm{L}^{-1}$ and from $30.5-139.3 \mathrm{mg} \mathrm{kg}^{-1}$ in the water and sediments samples, respectively.

The northern highland regions of Tanzania where the basin is located are part of the major East African Rift system. The geology of the Rift zones comprises of volcanic and intrusive rocks, largely of basaltic composition, but with some rare sodic alkaline rocks and igneous carbonates, therefore groundwater (hence probably surface waters too) in the Rift zone are characterised as typically alkaline in nature, with high concentrations of $\mathrm{HCO}_{3}{ }^{-}$, high $\mathrm{pH}$ values and relatively high $\mathrm{Na}^{+}$concentrations (Kilham, 1971), as was observed in this study 
Table 2: Concentrations of dissolved ionic species in the water $(\mathrm{mg} / \mathrm{l})$ and sediment $(\mathrm{mg} / \mathrm{kg})$ samples

\begin{tabular}{|c|c|c|c|c|}
\hline \multirow{3}{*}{ Ion } & \multicolumn{2}{|c|}{ Water Samples } & \multicolumn{2}{|c|}{ Sediment Samples } \\
\hline & Dry Season & Rainy Season & Dry Season & Rainy Season \\
\hline & Concentration range & Concentration range & Concentration range & Concentration range \\
\hline $\mathrm{Na}^{+}$ & $29.8-237$ & $20.5-190$ & $4.7-21.8$ & $9.5-33.1$ \\
\hline $\mathrm{K}^{+}$ & $1.4-25.0$ & $2.3-18.0$ & $0.8-7.4$ & $1.0-9.0$ \\
\hline $\mathrm{Mg}^{2+}$ & $3.9-52.0$ & $2.4-45.0$ & $0.1-4.6$ & $0.5-5.1$ \\
\hline $\mathrm{Ca}^{2+}$ & $6.1-43.7$ & $6.4-38.0$ & $0.1-9.8$ & $0.4-7.1$ \\
\hline $\mathrm{Li}^{+}$ & ND & ND & ND & ND \\
\hline $\mathrm{NH}_{4}^{+}$ & $\mathrm{ND}$ & ND & ND & ND \\
\hline $\mathrm{HCO}_{3}^{-}$ & $51-748$ & $27-633$ & $10.4-60$ & $16.4-97.4$ \\
\hline $\mathrm{SO}_{4}^{2-}$ & $1.0-164$ & $1.8-148$ & $0.7-51.7$ & $0.6-36.9$ \\
\hline $\mathrm{Cl}^{-}$ & $4.9-70.2$ & $3.8-68.0$ & $0.4-4.3$ & $0.4-4.8$ \\
\hline $\mathrm{F}^{-}$ & $0.17-4.02$ & $0.10-2.74$ & $0.1-0.8$ & $0.2-0.9$ \\
\hline $\mathrm{Br}^{-}$ & $0.35-1.05$ & ND & ND & ND \\
\hline $\mathrm{NO}_{2}^{-}$ & ND & ND & $0.1-2.0$ & $0.2-1.1$ \\
\hline $\mathrm{NO}_{3}^{-}$ & ND & ND & $0.1-0.8$ & $0.2-0.9$ \\
\hline $\mathrm{PO}_{4}{ }^{3-}$ & ND & ND & ND & ND \\
\hline
\end{tabular}

The observation that relatively higher concentrations of both $\mathrm{Na}^{+}$and $\mathrm{Cl}^{-}$ions were measured in locations closest to the Indian Ocean, and that the two ions were highly correlated $(\mathrm{r}=0.71$ at the 0.05 level, 2 tailed) indicate the possible influence of sea-salt. However, the highest concentration of $\mathrm{Na}^{+}(237 \mathrm{mg}$ $\mathrm{L}^{-1}$ ) at $\mathrm{S} 2$ indicates the possibility of additional inputs than natural sources. Normally all natural waters contain a certain concentration of $\mathrm{Na}^{+}$; however concentrations exceeding $200 \mathrm{mg} \mathrm{L}^{-1}$, which is also the WHO guideline limit for sodium in drinking water (WHO, 2004), are always associated with pollution, such as applications of Na-containing fertilizers.

Fluoride $\left(\mathrm{F}^{-}\right)$concentrations measured in this study, which ranged from 0.10 to $4.02 \mathrm{mg} \mathrm{L}^{-1}$ in the water samples, and from 0.10 to $0.90 \mathrm{mg} \mathrm{kg}^{-1}$ in the sediments, were higher than those previously reported in the area by PBWB/IUCN (2007). This ion occurs naturally in surface waters as a result of depositions of particulates from the atmosphere and the weathering of fluoride-containing rocks and soils. Its concentration in unpolluted fresh waters generally ranges from 0.01 to $0.3 \mathrm{mg} \mathrm{L}^{-1}$. The WHO standard of fluoride in drinking water is $1.5 \mathrm{mg} \mathrm{L}^{-1}$ (WHO, 2004). This level was exceeded in most of the stations in this study. Northern Tanzania is reported to be among the areas with high fluoride concentrations in natural waters, especially in areas surrounding the East African rift system with high volcanic activity.

High concentrations of $\mathrm{K}^{+}\left(25.0 \mathrm{mg} \mathrm{L}^{-1}\right)$ and $\mathrm{Mg}^{2+}$ $\left(52.0 \mathrm{mg} \mathrm{\textrm {L } ^ { - 1 }}\right)$ ions were measured at $\mathrm{S} 2$. Anthropogenic enrichment sources of $\mathrm{K}^{+}$ions include biomass burning, where $\mathrm{K}^{+}$ions in the form of $\mathrm{KCl}$ may be released to the environment from sugarcane burning, which is a common practice in the sugarcane plantations especially during harvesting seasons. Lara et al. (2001) specifically associated the ion with biomass burning. High concentration of $\mathrm{Mg}^{2+}$ ions at this station could be from natural weathering of rocks such as magnetite. Relatively high concentrations of $\mathrm{Ca}^{2+}\left(43.7 \mathrm{mg} \mathrm{L}^{-1}\right)$ and $\mathrm{SO}_{4}{ }^{2-}\left(164 \mathrm{mg} \mathrm{L}^{-1}\right)$ were measured at station S8. According to $\mathrm{PBWB} / \mathrm{IUCN}$ (2007), there exist some gypsum $\left(\mathrm{CaSO}_{4} \cdot 2 \mathrm{H}_{2} \mathrm{O}\right)$ deposits in the Mkomazi area, which is consistent with high concentrations of the two ions.

Nutrients: Of the three nitrogen compounds analysed, $\mathrm{NO}_{3}{ }^{-}-\mathrm{N}$ was the major component throughout the stations, detected in all of the samples, with concentrations ranging from 0.15 to $84 \mathrm{mg} \mathrm{L}^{-1}$ in the water samples; and from 0.50 to $29.1 \mathrm{mg} \mathrm{kg}^{-1}$ in sediments. Nitrate-nitrogen is the most oxidized chemical form of nitrogen found in the natural systems and also in living organism (Galloway and Cowling, 2002). Water samples from sampling station S8 were characterized by the highest concentration of $\mathrm{NO}_{3}^{-}-\mathrm{N}\left(84.0 \mathrm{mg} \mathrm{L}^{-1}\right)$, followed by S12 which had $32.3 \mathrm{mg} \mathrm{L}^{-1}$. These concentrations were highly elevated during the dry season than the rainy season. Both stations are located close to farmlands with intensive agricultural activities, therefore possible sources of this contamination are agricultural runoffs containing fertilizers.

Generally, the main contamination sources of surface waters by nitrate are potassium nitrate $\left(\mathrm{KNO}_{3}\right)$ and ammonium nitrate $\left(\mathrm{NH}_{4} \mathrm{NO}_{3}\right)$, both salts commonly used as fertilizers (Cole et al., 1993). These nitrogenous fertilizers, also used in the area, are said to rapidly convert into $\mathrm{NO}_{3}{ }^{-}$ions, which is highly soluble and hence easily leached (Howarth et al. 1996). Significantly high concentration of $\mathrm{NO}_{3}{ }^{-}-\mathrm{N}$ (29.1 $\mathrm{mg} \mathrm{kg}^{-1}$ ) was also measured in sediment samples at station S2, probably from eroded agricultural soils at the sugarcane plantations where inorganic fertilizers and other agrochemicals are extensively used.

The Environmental Protection Agency (EPA) sets the drinking water standard of $1 \mathrm{mg} \mathrm{L}^{-1}$ for $\mathrm{NO}_{2}^{-}-\mathrm{N} ; 10$ $\mathrm{mg} \mathrm{L}^{-1}$ for $\mathrm{NO}_{3}^{-}-\mathrm{N}$ and $10 \mathrm{mg} \mathrm{L}^{-1}$ for the sum of $\mathrm{NO}_{3}{ }^{-}-\mathrm{N}$ and $\mathrm{NO}_{2}{ }^{-}-\mathrm{N}$ (EPA, 1990). The WHO (2004) 
sets the drinking water guideline values of $50 \mathrm{mg} \mathrm{L}^{-1}$ for $\mathrm{NO}_{3}{ }^{-}-\mathrm{N}$. Both of these limits have been exceeded at some locations.

Ammonia-nitrogen $\left(\mathrm{NH}_{3}-\mathrm{N}\right)$ was a relatively minor component in both water and sediment samples. Concentrations of phosphorus $\left(\mathrm{PO}_{4}{ }^{3-}-\mathrm{P}\right)$ ranged from 0.01 to $0.29 \mathrm{mg} \mathrm{L}^{-1}$ in the water samples; and from below detection limit to $0.36 \mathrm{mg} \mathrm{kg}^{-1}$ in the sediment samples. Phosphorus is rarely found in high concentrations in fresh waters as it is actively taken up by plants (Dunne and Leopold, 1978).

Major elements: Concentration ranges of the major elements measured in sediments in this study are summarized in Table 3.

Table 3: Concentrations of major elements in sediment samples compared to background values

\begin{tabular}{lccc}
\hline Element $(\%)$ & $\begin{array}{c}\text { Dry Season } \\
\text { Concentration range }\end{array}$ & $\begin{array}{c}\text { Rainy Season } \\
\text { Concentration range }\end{array}$ & $\begin{array}{c}\text { Average Concentration in the Upper } \\
\text { Earth Crust }(\%) *\end{array}$ \\
\hline $\mathrm{Si}$ & $19.5-30.8$ & $20.0-32.7$ & 30.8 \\
$\mathrm{Al}$ & $6.23-13.4$ & $6.22-14.3$ & 8.04 \\
$\mathrm{Fe}$ & $2.72-9.41$ & $4.08-9.20$ & 5.0 \\
$\mathrm{Ca}$ & $<\mathrm{LOD}-6.36$ & $0.48-6.63$ & 3.6 \\
$\mathrm{~K}$ & $0.33-3.71$ & $0.33-1.85$ & 2.8 \\
$\mathrm{Ti}$ & $0.30-1.33$ & $0.42-1.16$ & 0.3 \\
$\mathrm{P}$ & $<$ LOD -0.1 & $<$ LOD & $<$ LOD \\
\hline & $<$ LOD $=$ Below Level of Detection & & $*$ Taylor and McLennan, 1985
\end{tabular}

The major elements' compositions in the sediment samples were within the estimated averages for the upper earth's crust and followed similar order of abundance, $\mathrm{Si}>\mathrm{Al}>\mathrm{Fe}>\mathrm{Ca}>\mathrm{K}>\mathrm{Ti}>\mathrm{P}$ (Taylor and McLennan, 1985). Concentrations of $\mathrm{Ti}$ were above the background estimated world average in all stations, while $\mathrm{Fe}$ and $\mathrm{Ca}$ were above estimated average values at a few locations, indicating that levels of the three elements are naturally high in the area.

Trace elements: Instrumental analysis of the water samples for trace-elements contamination showed that all targeted elements $(\mathrm{Pb}, \mathrm{Cu}, \mathrm{Cr}, \mathrm{Ni}, \mathrm{Cd}, \mathrm{Co}, \mathrm{As}$, $\mathrm{V}, \mathrm{Mn}$ and $\mathrm{Zn}$ ) were below the detection limits of the method. It can be concluded that water samples in the investigated locations were not contaminated by the analysed trace elements.
The concentration ranges, means and standard deviations of the 10 trace-elements measured in sediments from the twelve investigated stations during the dry and the rainy seasons are summarized in Table 4. Concentrations are compared to the upper earth crust values as approximations for a typical unpolluted environment (Taylor and McLennan, 1985).

The occurrences of trace elements in natural waters can be of natural sources such as from the earth crust, but also from anthropogenic origin. There is also a great deal of evidence that elemental contaminants can be spread as a result of long-range transport in such a way that natural ecosystems in areas remote from the sources of pollution may be contaminated.

Table 4: Trace elements conc. in sediments ( $\mathrm{mg} \mathrm{kg}^{-1}$ dry weight) compared to background values

\begin{tabular}{lccccc}
\hline Metal & $\begin{array}{c}\text { Dry season samples } \\
\text { Concentration } \\
\text { range }\end{array}$ & $\begin{array}{c}\text { Mean } \pm \text { SD } \\
(\mathrm{n}=12)\end{array}$ & $\begin{array}{c}\text { Concentration } \\
\text { range }\end{array}$ & $\begin{array}{c}\text { Mean } \pm \text { SD } \\
(\mathrm{n}=12)\end{array}$ & $\begin{array}{c}\text { Background values } \\
\begin{array}{c}\text { Upper Earth's } \\
\text { crust Abundance }\end{array}\end{array}$ \\
\hline $\mathrm{Cd}$ & $<\mathrm{LOD}-0.6$ & $0.4 \pm 0.1$ & $0.3-0.7$ & $0.4 \pm 0.1$ & 0.09 \\
$\mathrm{~Pb}$ & $7-46$ & $21 \pm 12$ & $13-45$ & $22 \pm 11$ & 20 \\
$\mathrm{~V}$ & $58-325$ & $155 \pm 88$ & $90-246$ & $142 \pm 50$ & 60 \\
$\mathrm{Cr}$ & $19-270$ & $79 \pm 65$ & $13-112$ & $65 \pm 25$ & 65 \\
$\mathrm{Mn}$ & $316-2610$ & $1200 \pm 800$ & $627-2940$ & $1500 \pm 800$ & 10 \\
$\mathrm{Co}$ & $12-50$ & $25 \pm 11$ & $21-47$ & $28 \pm 8$ & 20 \\
$\mathrm{Ni}$ & $14-85$ & $38 \pm 18$ & $13-59$ & $35 \pm 12$ & 25 \\
$\mathrm{Cu}$ & $26-57$ & $38 \pm 10$ & $30-114$ & $54 \pm 22$ & - \\
$\mathrm{Zn}$ & $73-355$ & $170 \pm 90$ & $73-270$ & $280 \pm 70$ & - \\
$\mathrm{As}$ & $1.1-5.1$ & $3.2 \pm 2.4$ & $1.6-5.3$ & $3.5 \pm 1.7$ & \\
\hline
\end{tabular}

*Taylor and McLennan, 1985

Results of this study revealed high concentration of $\mathrm{Cr}\left(270 \mathrm{mg} \mathrm{kg}^{-1}\right)$ at station $\mathrm{S} 12$ which differed significantly from the rest of the stations that ranged from 14 to $120 \mathrm{mg} \mathrm{kg}$. Furthermore, the concentrations of $\mathrm{V}\left(330 \mathrm{mg} \mathrm{kg}^{-1}\right)$ and $\mathrm{Cu}(114 \mathrm{mg}$ $\mathrm{kg}^{-1}$ ) were also exceptionally high at this particular station. The source of elemental pollution at S12 is probably the usage of agrochemicals since the sampling station is close to vegetable farms, where different types of agrochemicals such as copper sulphate are intensively used. The use of fertilizers and $\mathrm{Cu}$-containing agrochemicals has been 
documented as one pathway through which the elements are released into the natural environment (Shaw and Haddad, 2004). The lowest concentrations of most elements were measured at sampling locations S7 and S8, which are rather in rural settlements.

High levels of Ni were measured at station S2 during both seasons. This could possibly originate from anthropogenic sources since the station is close to the sugarcane plantations and the sugar processing industry. Among the known sources of anthropogenic release of $\mathrm{Ni}$ in the environment are forest fires and combustion processes, which are common in the sugarcane plantations (Cempel and Nikel, 2006).

Currently, Tanzania has set no guideline on the levels of trace metals in sediments of freshwater resources. The concentrations of environmentally significant metal contaminants in this study were therefore compared with existing sediment quality guidelines (SQG) from other regulatory agencies as shown in Table 5.

Table 5: Comparison of trace metal concentrations ( $\mathrm{mg} \mathrm{kg}^{-1}$ dry weight) in sediments to some SQGs

\begin{tabular}{|c|c|c|c|}
\hline Metal & This study range & TEC Value* & PEC Value* \\
\hline As & $1.1-5.3$ & 9.8 & 33 \\
\hline $\mathrm{Cd}$ & $0.3-0.7$ & 0.99 & 5.0 \\
\hline $\mathrm{Cr}$ & $13-268$ & 43 & 114 \\
\hline $\mathrm{Cu}$ & $26-114$ & 32 & 150 \\
\hline $\mathrm{Pb}$ & $7-46$ & 36 & 83 \\
\hline $\mathrm{Mn}$ & $316-2944$ & 460 & 1100 \\
\hline $\mathrm{Ni}$ & $14-85$ & 23 & 49 \\
\hline $\mathrm{Zn}$ & $73-355$ & 120 & 460 \\
\hline
\end{tabular}

Data in Table 5 show that concentrations of $\mathrm{Cr}, \mathrm{Mn}$ and $\mathrm{Ni}$ exceeded both the TEC and PEC at some locations, while concentrations of $\mathrm{Pb}$ and $\mathrm{Zn}$ exceeded only the TEC at some locations. However, it should also be noted that these data are provided only for comparison purposes; it must be pointed out that these guidelines were developed using different methodologies, each with its limitations, levels of acceptance, different extent of field validation, and differing degree of environmental applicability.

Organochlorine pesticide residues (OCP): A total of
18 OCP compounds were monitored in this study. These are $p, p^{\prime}$-DDE, $o, p^{\prime}-\mathrm{DDD}, o, p^{\prime}-\mathrm{DDT}, p, p^{\prime}-$ DDT, $\alpha-\mathrm{HCH}, \quad \beta-\mathrm{HCH}, \quad \gamma-\mathrm{HCH}, \quad \mathrm{HCB}, \quad \alpha-$ endosulfan, $\beta$-endosulfan, endosulfan sulfate, $\alpha$ chlordane, $\gamma$-chlordane, aldrin, dieldrin, endrin, heptachlor and heptachlor epoxide. Among the monitored compounds, seven of them were detected in water samples, while eight of them were detected in the sediment samples summarised in Table 6.

Table 6: OCP detected in the water and sediment samples

\begin{tabular}{|c|c|c|c|c|c|c|c|c|}
\hline \multirow{2}{*}{ Compound } & \multicolumn{4}{|c|}{ Water samples (pg/L) } & \multicolumn{4}{|c|}{ Sediment samples (pg/g d.w) } \\
\hline & $\%$ Detected & Min & Max & Mean & $\%$ Detected & Min & Max & Mean \\
\hline $\mathrm{HCB}$ & ND & - & - & - & 3 & 102 & 102 & 102 \\
\hline$\alpha-\mathrm{HCH}$ & 42 & 2000 & 4460 & 3350 & 72 & 107 & 990 & 317 \\
\hline$\beta-\mathrm{HCH}$ & 8 & 790 & 790 & 790 & 22 & 109 & 230 & 163 \\
\hline$\gamma-\mathrm{HCH}$ & 18 & 510 & 600 & 555 & 86 & 108 & 725 & 301 \\
\hline$\alpha$-Endosulfan & 33 & 370 & 500 & 437 & ND & - & - & - \\
\hline$\gamma$-Chlordane & 8 & 650 & 650 & 650 & ND & - & - & - \\
\hline$p, p^{\prime}-\mathrm{DDE}$ & 25 & 160 & 1460 & 690 & 94 & 106 & 7760 & 850 \\
\hline$o, p$ '-DDD & - & - & - & - & 11 & 105 & 190 & 150 \\
\hline$o, p '-\mathrm{DDT}$ & - & - & - & - & 53 & 117 & 1186 & 462 \\
\hline$p, p$ '-DDT & 58 & 320 & 1300 & 580 & 81 & 134 & 2043 & 755 \\
\hline
\end{tabular}

DDT compounds were the most detected found in over $80 \%$ of the samples, dominated by $p, p$ '-DDE, being indicative of past usage. Concentrations of the $p, p$ '-DDT ranged from 320 to $1300 \mathrm{pg} / \mathrm{L}$ in the water samples and from 134 to $2043 \mathrm{pg} / \mathrm{g}$ in the sediment samples. The highest concentrations of $\sum$ DDT in both sample matrices were measured at station S2 during the dry season. Apart from being close to the sugarcane plantations, station S2 is also impacted by other activities such as small-scale farming and home gardening, which could release residues into the rivers.

$\mathrm{HCH}$ isomers were also found in five stations ( $\mathrm{S} 2$, S3, S9, S10 and S11), where $\alpha-\mathrm{HCH}$ was the most frequently detected and had generally the highest concentrations. The relatively high ratio of $\alpha-\mathrm{HCH}$ compared to the other $\mathrm{HCH}$ isomers indicates the past usage of technical grade $\mathrm{HCH}$, which consists principally of $\alpha-\mathrm{HCH} \quad(70-80 \%)$ and smaller percentages of the other isomers (Tomlin, 2000). Technical grade $\mathrm{HCH}$ has been intensively used as a

\section{HARIETH HELLAR-KIHAMPA}


broad spectrum insecticide in the Arusha Chini sugarcane plantations in the past (Hellar and Kishimba, 2005). Concentrations of the other detected OCP were very low in both water and sediment samples. However it is worth noting that there are hundreds of other pesticide residues whose occurrences and concentration levels could not be established by this study.

Conclusions: This study characterized water and sediment samples from water sources in northern Tanzania for their physico-chemical parameters and concentration profiles of dissolved ionic species, nutrients, major elements, trace elements and organochlorine pesticide residues. The main goal was to quantify concentration levels of the micropollutants so as to assess quality of the water sources and highlight impacts of natural sources and human activities. The study compared the measured concentration levels with numerical benchmarks to establish ecotoxicological implications of the investigated chemicals. The chemical-to-land use approach was used to establish possible sources of the detected micropollutants.

Generally, with an exception of few locations, the physicochemical water quality parameters were within the range for natural water chemistry. The concentrations of dissolved ions showed that river waters were rich in $\mathrm{HCO}^{3-}$ and $\mathrm{Na}^{+}$, which was attributed to the geologic characteristics of the area, particularly the volcanic bedrocks. High concentrations of $\mathrm{Ca}^{2+}$ and $\mathrm{SO}_{4}{ }^{2-}$ at one location were attributed to the natural sources of gypsum. The impact of sea-salt on concentrations of $\mathrm{Na}^{+}$and $\mathrm{Cl}^{-}$, particularly in locations close to the Indian Ocean, was also established. A few of the ions were found to be enriched from human activities at some locations. Concentration levels of some toxic metals $(\mathrm{Pb}, \mathrm{Cr}$, $\mathrm{Ni}$ ) were high enough at some points to raise ecotoxicological concerns. The analytical results also indicated the presence of low concentrations of organochlorine pesticide compounds, especially DDTs and $\mathrm{HCH}$ isomers, with trends that indicate past usage in large-scale agricultural establishments as the main source.

The evidence from these results suggests that, as previously suspected, water sources in the area are indeed contaminated by some chemical species from different sources. Moreover, analysis of the trends and patterns of the data show that both human activities and natural sources contributed to the inputs of chemical species into the river systems, with the later having more impact. Although comparisons between the obtained concentration levels and established water and sediment quality standards showe relatively low level of ecotoxicological risks, the indications of anthropogenic contamination of water sources in this area call for particular attention. We recommend further investigations to establish specific pollution contributions from various key sources, as well as investigating other chemical species that were not analyzed in this work, especially those of significance to surface water contamination.

Acknowledgements: This work was financially supported by the Belgian Development Agency (BTC) through a scholarship grant to the author. The author appreciates support given by the Pangani Basin Water Board, Kilimanjaro, Tanzania during sampling campaigns and technical assistance from the Department of Chemistry, University of Dar es Salaam; Laboratory of the School of Environmental Science and Technology, Ardhi University, Dar es Salaam; the Government Chemists Laboratory Agency, Dar es Salaam, Tanzania and the Departments of Chemistry, University of Antwerp Belgium.

\section{REFERENCES}

APHA/AWWA/WEF, (2005). American Public Health Association, American Water Works Association, and the Water Environment Federation Standard Methods for the Examination of Water and Wastewater. 21st ed. Alexandria, VA: WEF Publishing.

Bartram J; Ballance R (1996). Water quality monitoring: a practical guide to the design and implementation of freshwater quality studies and monitoring programmes ( $1^{\text {st }}$ ed.): London: E \& FN Spon.

Beuster, J; Howard, GJ; Lugomela, GV (2006). Pangani Basin Flow Assessment Initiative: Hydrology and System Analysis Volume 1. Southern Waters Ecological Research and Consultants and Anchor Consultants.

Chapman, D; Kimstach, V (1996). Selection of water quality variables. In: Chapman, D. (ed.), Water quality assessments: a guide to the use of biota, sediments and water in environmental monitoring. E \& FN Spon. London, pp. 59-125.

Cempel, M; Nikel, G (2006). Nickel: A review of its sources and environmental toxicology. Pol. J. Environ. Stud 15, 375-382.

Cole, JJ; Peierls, BL; Caraco, NF; Pace, ML (1993). Nitrogen loading of rivers as a human-driven process. Pp 141-157. In: M. J. McDonnell and S. T. A. Pickett, (Eds.) Humans as components of ecosystems. Springer-Verlag, New York, New York, USA. 
DeZuane, PEJ (1997). Chemical parameters inorganics. In: DeZuane, P.E.J. (Ed.), Handbook of Drinking Water Quality. Van Nostrand Reinhold, New York, pp. 49-148.

Dunne, T; Leopold, LB (1978). Chemical characteristics of water. In: Dunne, T., Leopold, L.B. (Eds.), Water in Environmental Planning. W.H. Freeman and Company, New York, pp. 727-766.

Eggen, T; Moeder, M; Arukwe, A (2010). Municipal landfill leachates: A significant source for new and emerging pollutants. Sci. Total Environ. 408, 5147-5157.

EPA (1990). Environmental Protection Agency. Drinking Water Criteria on Nitrate/Nitrite, Office of Drinking Water, Washington, DC.

Fitzpatrick, ML; Long, DT; Pijanowski, BC (2007). Exploring the effects of urban and agricultural land use on surface water chemistry, across a regional watershed, using multivariate statistics. Appl. Geochem. 22, 1825-1840.

Galloway, JN; Cowling, EB( 2002). Reactive nitrogen and the world: 200 years of change. Ambio 31, 64-71.

Hellar, H; Kishimba, MA (2005). Pesticide residues in water from TPC sugarcane plantations and environs, Kilimanjaro region, Tanzania. Tanzania J. Sci. 31, 13-22.

Hellar-Kihampa, H. 2011. Pesticide residues in four rivers running through an intensive agricultural area, Kilimanjaro, Tanzania. J. Appl. Sci. Environ. Manage. 15(2) 307-316.

Hellar-Kihampa, H; Potgieter-Vermaak, S; De Wael, K; Lugwisha, E; Van Espen P; Van Grieken, R (2014). Concentration profiles of metal contaminants in fluvial sediments of a ruralurban drainage basin in Tanzania. Int. J. Environ. Anal. Chem. 94(1) 77 - 98.

Howarth, RW; Billen, G; Swaney, D; Townsend, A; (1996). Regional nitrogen budgets and riverine inputs of $\mathrm{N}$ and $\mathrm{P}$ for the drainages to the North Atlantic Ocean: natural and human influences. Biogeochemistry 35, 75-139.

Kilham, P (1971). Biogeochemistry of African Lakes and Rivers. Duke University, Durham, N.C. 199pp.

Kishimba, MA; Henry, L; Mwevura, H; Mmochi, AJ;
Mihale, M; Hellar, H (2003). The Status of Pesticide Pollution in Tanzania. Talanta 64, 4853.

Lara, LBLS; Artaxo, P; Martinelli, LA; Victoria, RL; Camargo, PB; Krusche, A; Ayers, GP; Ferraz, ESB; Ballester, MV (2001). Chemical composition of rainwater and anthropogenic influences in the Piracicaba River Basin, Southeast Brazil. Atmos. Environ. 35, 49374945.

Manahan, S (2005). Environmental Chemistry, $8^{\text {th }}$ Edition. CRC Press LLC.

Msogoya, TJ ; Maerere, AP (2006). The Flower Industry in Tanzania: Production Performance and Costs. Agron. J. 5, 478-481.

Ngoye, E; Machiwa JF; (2004). The influence of land-use patterns in the Ruvu river watershed on water quality in the river system. Phys. Chem. Earth, 29, 1161-1166.

PBWB/IUCN (2007). Pangani Basin Water Board and the International Union for Conservation of Nature and Natural Resources. River Health Assessment Report. Pangani River Basin Flow Assessment. Moshi, Tanzania, 121pp.

Schlautman, MA; Han, I (2001). Effects of pH and dissolved oxygen on the reduction of hexavalent chromium by dissolved ferrous iron in poorly buffered aqueous systems. Water Res. 35, 15341546.

Shaw, MJ and Haddad, PR (2004). The determination of trace metal pollutants in environmental matrices using ion chromatography. Environ. Int. 30, 403-431.

Taylor, SR; McLennan, SM (1985). The Continental Crust: its Composition and Evolution. Oxford: Blackwell, 312 pp.

Tomlin, C (2006). The Pesticide Manual: A World Compendium, $14^{\text {th }}$ Ed., The British Crop Protection Council (BCPC), Alton, Hampshire.

WCW (1999). World Commission on Water. World's Rivers in Crisis - Some are Dying; Others Could Die. World Water Council, GEO-2-124.

WHO (2004). World Health Organization. Guidelines for Drinking-water Quality. $3^{\text {rd }}$ Ed., Recommendations, Vol. 1, pp. 191-192, Geneva. Switzerland. 